rigour is lacking, provided it affords insight. 'The naive treatment of viscosity is given, though to be sure it is followed soon enough by an account which does not assume Maxwellian distribution of velocitios ; there are parallel treatments of thermal conductivity. On the other hand, no attempt is made to include simple theories in the sections on diffusion and thermal diffusion.

In the final chapters on gas imperfections and intermolecular forces, the fashionable 6-12 potential function is severely scrutinized, and the difficulty of obtaining inter-molecular potential functions from second virial coefficients alone is exposed. A synthetic five-parameter function is advanced and shown, for argon, to give an impressive account of the dependence on temperature not only of the second virial coefficient but also of the entropy, heat content and density of the solid.

The book is aimed at graduate and research workers, but the mathematical treatment is such that undergraduates in their final year could profitably read much of the earlier and later chapters of the book. It is not only part of an encyclopadis to be consulted and referred to, but also a book to be read and enjoyed.

D. J. MULEN

\section{INVISIBLE LUNATIC}

\section{Automatic Translation}

By D. Yu Panov. Translated from the Russian by R. Kisch. Edited by A. J. Mitchell. Pp. vii +73 . (London and New York: Pergamon Press, 1960.) 21s. net.

\section{Automatic Language Translation}

Loxical and Technical Aspects, with particular reference to Russian. By Prof. Anthony G. Oettinger. (Harvard Monographs in Applied Science, No. 8.) Pp. xix +380 . (Cambridge, Mass. : Harvard University Press; London: Oxford University Press, 1960.) 80s. net.

THE title of this review is prompted by the story, until recently apocryphal, that a Russian computer translated the phrase "Out of sight, out of mind" from the English and that an American machine, in due course, re-translated the Russian back into English with the above result.

In so far as this story has a point, it is illustrated by the two books under reviow. Both are the first generally available technical reports produced by mechanical translation workers in their respectivo countries. By saying this I do not in any way moan to neglect the volumes of brief essays which have already appoared or the excellent reports, of limited circulation, which some American groups have issued.

Both books describe the activities of single groups of workers, and both are coloured by the particular machines used for the experiments.

Panov's book starts by discussing how human beings go about the act of translation, and then, after examining the characteristics of scientific and tech. nical prose, describes the electronic computer Besm 1 and experiments made with its aid in this field. Detailed programmes are analysed and there is a critical survey of the present theories of translation.

Oettinger follows similar lines, except that his machine is the Univac 1 , and that he is far loss concerned with translation theories than with the precise details of Russian-English dictionary construction.

On balance it is fair to say that Panov's book will be far more readable to the non-specialist and, correspondingly, far less useful to workers in the field. Oettinger's book is nearly five times as long and is packed with useful data for the specialist.

Both books are excellently written and can be thoroughly recommended.

A. D. Bоoтн

\section{ALL ABOUT MANGOES}

\section{The Mango}

Botany, Cultivation, and Utilization. By Dr. Lal Behari Singh. (World Crops Books.) Pp. xiii $+438+$ 54 plates. (London: Loonard Hill (Books), Ltd. ; New York: Interscience Publishers, Ino., 1960.) 84s. not.

$\mathrm{T}$ is pleasing, as it is unexpected, to find a new series of books on world crops starting off not with such solid fare as wheat or potatoes or cabbage but with somothing as exotic and appetizing as the mango. This "choicest fruit of Hindoosthan" has spread far beyond the bounds of India and has become one of the most cherished fruits of tropical lands. It is still found in greatest variety and excellence in India, and this book comes, fitly enough, from the pen of a distinguished Indian horticulturist.

The book may be counted on to commend itself as the most complete study of the mango so far published. There has indeed been a recent book, also entitled The Mango, which splendidly described the Indian varieties, but had only a short account of their cultivation. Dr. Singh deals with the subject on a broader front, concerning himself not only with the botany and requirements but also with propaga. tion and management, the diseases and pests to be withstood, and the uses to which the mango is put.

While the botanical chapters refer mainly to the common mango, $M$. indica, the author directs attention to fifteen other species of Mangifera with edible fruits. Evidently there is great wealth of related material here, of possible value for future breeding. A clear and well-illustratod account is given of methods of vegetative propagation. In describing the practice of cultivation, the author is strangely insistent that the established orchard needs ploughing twice a year to maintain a proper soil tilth. It is not clear why such a disturbance is preferred to maintenance of a more natural leaf-litter. The section on utilization is necessarily brief, since the best way to use a mango is still to eat it as promptly and as dexterously as possible, but some mango recipes are also given. A full bibliography and a good index complete the work.

The book could have done with some tidying up, for misprints and some not quite lucid passages occur. In striving for completeness, the author tends to length, and his more impatient readers may grudge the space given to explaining what a horticultural variety is, or the detail spent on different methods of applying irrigation water to a treo which, over much of its range, is satisfied by the rain from hasven. In giving such full measure, the author doubtless errs on the right side, and his book deserves to be welcomed and to be gratefully added to the small, but growing, collection of hand-books on the tropical crops.
T. A. Russell 